\title{
Residents' Attitudes toward Impacts of Tourism: A Case Study of Langkawi, Malaysia
}

\author{
NURHAZANI MOHD. SHARIFF \\ SHAHARUDDIN TAHIR \\ Faculty of Tourism, \\ Hospitality and Environmental Management \\ Universiti Utara Malaysia
}

\begin{abstract}
This paper presents findings from a study that was undertaken to investigate residents'attitudes toward the impacts of tourism in Langkawi Island, Malaysia. In order to gain reliable results for the use of Langkawi policy makers and tourism planners, a standardized instrument for measuring residents' attitude was developed and used in the study. The findings revealed that residents tend to perceive impacts that benefit them as positive impacts of tourism. The findings also indicated that residents tend to perceive impacts of tourism, either positively or negatively depending on how much they would affect their personal lives. The more dependent they were on the positive impacts of tourism, the more supportive they were toward tourism development. Thus, the findings do not support Doxey's Irridex Model. Finally, the study suggested that for a long-term purpose of achieving sustainable tourism development, Langkawi tourism planners and policy makers should conduct several campaigns and tourism workshops for the residents. Accordingly, this would gain residents support for tourism development on the island.
\end{abstract}

\begin{abstract}
ABSTRAK
Artikel ini membentangkan kajian yang telah dijalankan bagi mengenal pasti sikap penduduk terhadap impak pelancongan di Pulau Langkawi, Malaysia. Untuk mencapai satu keputusan yang kukuh dan bermakna bagi kegunaan pembuat dasar dan perancang pelancongan di Pulau Langkawi, satu pengukur yang piawai digunakan untuk mengukur sikap penduduk dalam kajian ini. Hasil kajian mendapati penduduk lebih cenderung menerima impak pelancongan yang positif apabila mereka menerima banyak kebaikan daripada pelancongan tersebut. Malah, hasil kajian juga mendapati bahawa penduduk akan lebih cenderung menerima impak pelancongan sama ada positif atau negatif bergantung kepada pengaruh impak tersebut ke atas kehidupan mereka. Semakin banyak mereka bergantung kepada impak pelancongan yang positif, semakin kuat sokongan mereka terhadap pembangunan pelancongan di tempat mereka. Kesimpulannya, hasil kajian ini tidak menyokong Model Irridex oleh Doxey. Berdasarkan hasil kajian yang dijalankan, dicadangkan bagi mencapai pelancongan mapan dalam jangka panjang, perancang pelancongan Langkawi dan pembuat dasar perlu mengadakan beberapa kempen kesedaran dan seminar kepada penduduk Langkawi. Ini kemungkinan akan membawa kepada sokongan penduduk terhadap pembangunan pelancongan di pulau tersebut.
\end{abstract}




\section{INTRODUCTION}

Currently, studies on residents' attitudes toward tourism have become an important subject in tourism research. In fact, the congruency in attitudes toward tourism is stressed in several tourism studies (Akis et al., 1988; Andereck \& Vogt, 2002; Hernandez et al., 1996; Lankford, 1994; Lindberg \& Johnson, 1997; Liu \& Var, 1986; McCool \& Martin, 1994). The importance of studying attitudes is also noted by Ryan et al. (1998) in a comparative study between the Rangitikei, New Zealand and Bakewell, United Kingdom. They stress that: "attitudes are important in a number of ways: they are perceived to be important because of the values held by a person, they are indeed, the expression of values and their application to specific events" (pg.117).

Accordingly, studies on residents' attitudes toward tourism focus on three main impacts of tourism, which are, economic, environmental and socio-cultural. As noted by Jafari (1977), early work in tourism research focused on the positive impacts of tourism, where in the 1970s' it focused on the negative impacts of tourism; and in the 1980s, it focused on a more balanced and systematic approach. For the purpose of understanding residents' attitude toward tourism, Doxey's (1975) Irridex Model has been used as a framework in studying relationship between changing attitudes and the level of tourism development. The model claims that residents' attitudes will go through a number of stages from 'euphoria' to 'apathy', 'annoyance' and 'antagonism' (Table 1). The word 'Irridex' actually means Irritation Index which explains residents' reactions towards tourists change according to the cycles of the destination development. Doxey also suggested that residents' attitudes toward tourism firstly are positive, then changes to irritability and will change to resentment in later stages of the development.

The model is supported by Lankford (1994) where he finds that residents of the Columbia River Gorge appear to be more negative toward the impacts of tourism as it develops in the area.
They feel that negative impacts of tourism have increased owing to tourism. In addition, Ryan et al. (1998) tested the hypothesis that the more developed a tourist destination is, the greater is the likelihood that residents will be less favorably disposed to tourism. It was found that even though the Rangitikei residents support tourism in the area, there is a reduction in support for tourism as tourism develops.

However, the practical part of using and applying the model is still a crucial issue in attitude study for tourism research. Several studies have found that the model is not applicable in certain communities because residents favor impacts of tourism based on the fact that their lives are completely dependent on tourism. According to Allen et al. (1993), residents' attitudes are affected by the level of economic activity and not the level of tourism development. Their findings do not support previous research that suggests attitudes toward tourism will become less positive with high levels of tourism development. In another study, Snaith \& Haley (1999), indicated that residents who felt tourism was important to their occupation were more likely to feel positive toward its presence. This shows that residents who are dependent on tourism, accept the development of tourism more positively. In accordance, a previous research by Akis et al. (1996) also suggests that residents become more positive are they see their lives are completely dependent on tourism. In fact, they also found that there is a significant relationship between the levels of income and the positive attitude toward tourism.

Expanding the model, Butler (1975) came out with another stage of destination development known as Product Life Cycle (PLC). PLC consists of several stages beginning with exploration, involvement, development, consolidation and finally, stagnation. Since Langkawi is considered as being in a new development stage, the study uses Doxey's Irridex Model in understanding residents' attitudes toward tourism. It should also be noted that attitudes do not predict support for tourism development very well in the tourism communities. This is supported by Andereck \& Vogt (2000) where they found that community 
Table 1

Doxey’s Irridex Model 1975

\begin{tabular}{|l|l|l|}
\hline & Social Relationships & Power Relationships \\
\hline Euphoria & Visitors \& investors welcome & $\begin{array}{l}\text { Little planning or formalized } \\
\text { control }\end{array}$ \\
\hline Apathy & $\begin{array}{l}\text { Visitors taken for granted } \\
\text { Formal relationships between } \\
\text { hosts \& guests }\end{array}$ & $\begin{array}{l}\text { Marketing is the prime } \\
\text { focus of plans }\end{array}$ \\
\hline Annoyance & $\begin{array}{l}\text { Residents misgivings about } \\
\text { tourism }\end{array}$ & $\begin{array}{l}\text { Planners attempt to control } \\
\text { by increasing infrastructure }\end{array}$ \\
\hline Antagonism & Irritations openly expressed & $\begin{array}{l}\text { Power struggle between } \\
\text { interests groups }\end{array}$ \\
\hline
\end{tabular}

Source: Doxey (1975)

benefits of tourism perceived by residents have a direct and positive relationship to support tourism development. However, the positive attitudes toward tourism are not strongly related to additional development of tourism products and the negative attitudes may not decrease residents' desire for development. Thus, it can be concluded that there is a relationship between attitudes and support for development although the nature of the relationship is different for each community.

Based on this scenario, several questions arise such as, how do residents react to tourism development in their area? Do their lives depend on tourism development? Do their support for tourism depends on whether they receive positive impacts from tourism? These questions need to be researched. Thus, a study was undertaken with the purpose to examine the attitudes of the residents toward impacts of tourism in Langkawi, Malaysia. The objectives of the study are:

i. to identify the positive impacts of tourism perceived by the residents,

ii. to identify the negative impacts of tourism perceived by the residents, and

iii. to test whether Doxey's Irridex Model is applicable in the case of Langkawi.

\section{CASE STUDY: LANGKAWI}

There are several studies on residents' attitudes toward tourism in Malaysia. A study in Langkawi and Penang indicated that residents favor economic impacts of tourism because they received direct benefits from tourism development such as more job opportunities (Din, 1993). However, contrast findings are found in a study in the state of Kedah, Malaysia, where it was found that locals actually perceived the impacts of tourism negatively because tourism is not a major economic contributor to the state (Mohd. Shariff et al., 2000). In a later study by Kayat \& Propst (2001) in Langkawi, residents' general values, their dependence on tourism, and their ability and willingness to adapt, were found to moderate the influence the power of the residents' evaluation of tourism impacts. The study also indicated that residents' attitudes toward tourism are based on their evaluation of the returns that they receive from the exchanges.

There are, only a few studies on residents' attitudes toward impacts of tourism in Langkawi. The purpose of this study is to research several 
questions with regards to tourism in Langkawi. Is Doxey's Irridex Model applicable in the case of tourism development in Langkawi? Do the residents of Langkawi accept tourism development positively? Do the positive impacts of tourism influence the attitudes of residents toward tourism development in the area? The answers are important to the tourism planners and policy makers in order for them to manage sustainable tourism development in Langkawi.

Langkawi is an island located north of Peninsular Malaysia in the state of Kedah. It is geographically divided into six districts, i.e. Kuah, Padang Matsirat, Ayer Hangat, Bohor, Ulu Melaka and Kedawang. With a population of more than 62,000, Langkawi consists of an estimated 91.2 percent of Malays, 5.1 percent of Chinese and 2 percent of Indians (Langkawi Residential/ SocioEconomic Study, 1999). It has developed a legend of its own and at present captures a total of 1,378,940 tourist arri-vals (Langkawi Development Authority, 1999). Langkawi was first developed as a major tourist destination in 1984 and since 1990, the government has allocated RM320 million for the deve-lopment of infrastructure and public facilities. In addition, under the Sixth Malaysia Plan 1991- 1995, the government allocated RM350 million for the socio-economic and infrastructure deve-lopment on the island (North Review, 1995).

In order to be involved directly in the tourism development of Langkawi, the federal government established Langkawi Development Authority (LADA) in 1990. Under Act 423, LADA is responsible to stimulate, implement, expedite and execute socio-economic development in Langkawi. Due to the first campaign "Visit Malaysia Year" in 1990, Langkawi had 783,687 million tourists and the number increased to 1,598,126 for the second campaign "Visit Malaysia Year" in 1994. However, the number of tourists arrivals in Langkawi declined between 1996-1998 due to several incidents such as cholera outbreak and the coxsackie virus. In 1999 , the number increased to $1,559,528$ and this indicated that LADA had succeeded in promoting and marketing Langkawi as an international tourist destination.

\section{METHODOLOGY}

This descriptive study intended to describe the attitudes of residents in Langkawi toward impacts of tourism in the area. The studys' population was residents of Langkawi that consisted of 62,617 people. For the purpose of the study, residents are defined as people who have stayed, and at the same time lived in Langkawi and were still living there during the period of the study. Using probability proportionate to size (PPS) method of sampling, 145 respondents were selected as a sample for the study.

The sample size was determined by the remaining items in the pretest questionnaire (Tinsley \& Tinsley, 1987). The respondents were sampled from each district; Kuah, Padang Matsirat, Ayer Hangat, Bohor, Ulu Melaka dan Kedawang. To enable each resident in each district to have an equal chance of being drawn into the sample, the number of residents in each district were divided by the total number of residents in Langkawi and then multiplied by the number of the sample size (Table 2).

In order to gain information and data from the respondents, a standardized scale for measuring attitude was developed following the procedures recommended by Churchill (1979), DeVillis (1991) and Zaichowsky (1985). A questionnaire was designed and the Fishbein's Attitude Model was used as a formula to measure the attitude of the residents. According to Fishbein (Fishbein, 1963:6), "a significantly better estimate of attitude is found by taking both the belief and evaluative aspects of an object into account".

The questionnaire consisted of two main parts. The first part was designed for the purpose of measuring the "belief" component. The respondents were asked to indicate the level of change caused by tourism. A five-point Likert scale was used to rate the level of change associated with each item by indicating, $1=$ large decrease, $2=$ moderate decrease, $3=$ no change, $4=$ moderate increase and $5=$ large increase. . An additional sixth-point was placed as a category for the " $d o$ not know" response. The second part of the questionnaire consisted of items used to measure the "evaluative" component of attitude. The respondents were asked to indicate the level of like/dis- 
Table 2

Sample Size for Each District of Langkawi

\begin{tabular}{|lcc|}
\hline District & Number of Residents & Number of Sample \\
\hline Kuah & 23,750 & 55 \\
Ulu Melaka & 9,417 & 22 \\
Ayer Hangat & 8,458 & 20 \\
Kedawang & 8,050 & 19 \\
Padang Matsirat & 7,654 & 18 \\
Bohor & 5,288 & 11 \\
\hline Total & 62,617 & 145 \\
\hline
\end{tabular}

like toward tourism. A five-point Likert scale was also used to measure the level of like/dislike by indicating, 1 = dislike, 2 = somewhat dislike, $3=$ neither like nor dislike, $4=$ somewhat like and $5=$ like. In addition, the questionnaire also required some information with regard to the respondents' employment, the number of years living in Langkawi, age group and also racial group. This part was in the final part of the questionnaire.

The data were then analyzed using SPSS (Statistical Package for the Social Sciences) 10.0 for Windows. Results of the scale development indicated a reliable and valid attitudinal scale. Five factors were derived from the factor analysis and were identified as environmental, amenity services, socio-cultural, community attitude and economic. In addition, results of the reliability analysis indicated a strong Cronbach's alpha value for all the five factors derived from the scale, that ranged from 0.64 to 0.89 . The scale also consisted of 13-item with an alpha scale coefficient of 0.774 .

\section{RESULTS}

As the questionnaires were given to the respondents and were collected at the same time, all the 145 questionnaires were returned. Results of the frequency and percentage analysis (Table 3 ) indi- cated that from the total of 145 respondents, 81.4 percent were working in the tourism related-sector while 18.6 percent were working in other sectors. This could probably be explained by the fact that the majo-rity of the respondents were residents living in the areas that consist of all the major sectors in tourism and hospitality.

The results also indicated that majority of the respondents (86.9\%) had lived in Langkawi for more than 6 years, 6.9 percent had lived in Langkawi for about 4 to 6 years, 4.1 percent had lived in Langkawi for about 1 to 3 years and only 2.1 percent had lived in Langkawi for less than 1 year. In addition, the results indicated that majority of respondents were above 50 years old ( $34.5 \%$ ), followed by 43.4 percent in the 40 to 50 age group, 16.6 percent was in the 20 to 39 age group and only 5.5 percent was below 20 years old. Accordingly, the respondents consisted of different racial groups. 58.6 percent of the respondents were Malays, followed by 17.2 percent of other races, 15.9 percent Chinese and 8.3percent Indians.

From the analysis, the findings revealed that residents tend to perceive impacts that benefit them as positive impacts of tourism. They believed, and accordingly, evaluated these impacts positively. Moreover, they also favored the changes caused by tourism in the area (Table 4 ). 
Table 3

Demography of the 145 Respondents

\begin{tabular}{|lc|}
\hline & Percentage (\%) \\
\hline Working in the tourism related-sector & 81.4 \\
Working in other sectors & 18.6 \\
\hline Lived in Langkawi for more than 6 years & 86.9 \\
Lived in Langkawi for about 4-6 years & 6.9 \\
Lived in Langkawi for about 1-3 years & 4.1 \\
Lived in Langkawi for less than 1 year & 2.1 \\
\hline Above 50 years old & 34.5 \\
40 - 50 years old & 43.4 \\
20 - 39 years old & 16.6 \\
Below 20 years old & 5.5 \\
\hline Malays & 58.6 \\
Other races & 17.2 \\
Chinese & 15.9 \\
Indians & 8.3 \\
\hline
\end{tabular}

- 96.5 percent of the respondents favored the changes caused by tourism in the local services (police, fire, medical and utilities). Majority of the respondents favored the changes caused by tourism in the aspect of the amenity services. In fact, all the respondents favored the changes caused by tourism in the variety of restaurants in the area. Meanwhile, 97.2 percent of the respondents favored the changes caused by tourism in the amount of investment spending in the area.

The findings also revealed that most of the changes caused by tourism in the socio-cultural aspect were very much favored by the respondents. 99.3 percent of them favored the changes caused by tourism in the demand for historical activities and programs in the area. In addition, 96.6 percent favored the changes caused by tourism in the cultural activities and programs in the area. The findings of the study also revealed that 84.8 percent of the respondents favored the changes caused by tourism in their standards of living. Mean- while, 83.5 percent of the respondents favored the changes caused by tourism in the opportunities to restore and protect historical structures in the area.

In addition, the findings revealed that residents tend to perceive the increment of the impacts that benefit them, positively (Table 5). 80.0 percent found that tourism had increased the level of capacity of local services (police, fire, medical and utilities) to perform their services in the area. 99.3 percent of them indicated that tourism had increased the variety of restaurants in the area. Meanwhile, 98.6 percent indicated that tourism had increased the amount of investment spending in the area. The findings also found that 97.9 percent of the respondents indicated that tourism had increased the demand for historical activities and programs in the area. In addition, 98.6 percent of them stated that tourism had increased the demand for cultural activities and programs in the area. These findings are similar to the studies by Liu 
Table 4

Impacts of Tourism Favored by Residents

\begin{tabular}{|lcc|}
\hline Impacts & Frequency & Percentage (\%) \\
\hline $\begin{array}{l}\text { Capacity of local } \\
\text { services }\end{array}$ & 140 & 96.5 \\
Variety of restaurants & 145 & 100.0 \\
Investment spending & 141 & 97.2 \\
$\begin{array}{l}\text { Demand for historical } \\
\text { activities }\end{array}$ & 144 & 99.3 \\
$\begin{array}{l}\text { Demand for cultural } \\
\text { Activities }\end{array}$ & 140 & 96.6 \\
Standard of living & 123 & 84.8 \\
$\begin{array}{l}\text { Restore and protect } \\
\text { historical structures }\end{array}$ & 121 & 83.5 \\
\hline
\end{tabular}

Table 5

Positive Impacts Perceived by Residents

\begin{tabular}{|lcc|}
\hline Increment of Impacts & Frequency & Percentage (\%) \\
\hline $\begin{array}{l}\text { Capacity of local } \\
\text { services }\end{array}$ & 116 & 80.0 \\
Variety of restaurants & 144 & 99.3 \\
Investment spending & 143 & 98.6 \\
$\begin{array}{l}\text { Demand for historical } \\
\text { activities }\end{array}$ & 142 & 97.9 \\
$\begin{array}{l}\text { Demand for cultural } \\
\text { activities }\end{array}$ & 143 & 98.6 \\
$\begin{array}{l}\text { Residents' standard of } \\
\text { living }\end{array}$ & 125 & 86.2 \\
\hline
\end{tabular}


\& Var (1986) and McCool \& Martin (1994). Meanwhile, 86.2 percent of them stated that tourism had increased their standard of living.

The results also revealed that respondents tend to perceive the impacts of tourism that they did not favor, negatively (Table 6). 73.2 percent of the respondents did not favor the changes caused by tourism in the wildlife aspect (plants, birds and animals). In another aspect, 42.1 percent of the respondents did not favor the changes caused by tourism in the amount of local taxes collected. 91.7 percent of them did not favor the changes caused by tourism in the level of noise in the area.

Table 6

Impacts of Tourism Not Favored by Residents

\begin{tabular}{|lcc|}
\hline Impacts & Frequency & Percentage (\%) \\
\hline Changes in wildlife & 106 & 73.2 \\
$\begin{array}{l}\text { Changes in local } \\
\text { taxes collected }\end{array}$ & 61 & 42.1 \\
$\begin{array}{l}\text { Changes in level of } \\
\text { noise }\end{array}$ & 133 & 91.7 \\
\hline
\end{tabular}

The findings also revealed that respondents tend to perceive negatively several impacts of tourism that did not benefit them (Table 7). 71.0 percent of the respondents stated that tourism had decreased the wildlife in the area. However, several impacts that had increased due to tourism de- velopment in the area were perceived as negative impacts of tourism. 71.7 percent of the respondents indicated that tourism had increased the amount of local taxes in the area. In addition, 93.8 percent of them indicated that the noise level in the area had increased due to tourism.

Table 7

Negative Impacts Perceived by Residents

\begin{tabular}{|lcc|}
\hline Impacts & Frequency & Percentage (\%) \\
\hline $\begin{array}{l}\text { Decrease of wildlife } \\
\begin{array}{l}\text { Increase in local taxes } \\
\text { collected }\end{array}\end{array}$ & 103 & 71.0 \\
$\begin{array}{l}\text { Increase in the level } \\
\text { of noise }\end{array}$ & 104 & 71.7 \\
\hline
\end{tabular}


The findings also revealed that respondents neither liked nor disliked the changes caused by tourism in the community attitude aspect. 86.9 percent of them stated that tourism did not bring any changes in the community spirit among the residents. Moreover, the findings also indicated that 88.3 percent stated that tourism did not change the pride of the local residents.

\section{DISCUSSIONS}

Based on the number of years living in Langkawi, the findings are significant because majority of the respondents have gone through the stages of tourism development in the area. Thus, they can express their believes and evaluate the questions more accurately. The results also indicate that residents tend to perceive impacts that benefit them as positive impacts of tourism. These are impacts that have increased due to tourism, such as, the capacity of local services (police, fire, medical and utilities) in performing their services, the variety of restaurants in the area, the amount of investment spending, the demand for historical and cultural activities and programs, the residents' standard of living and the opportunities to restore and protect the historical structures in the area. An increase in the variety of restaurants would have provided job opportunities for the residents.

The results of the analysis also revealed that items such as changes in prices, changes in income and pollution were not derived in the first place during the purification of the instrument. However, the positive attitudes probably can be explained by the fact that tourism development in Langkawi has led the government to increase the level of capacity particularly of the local services (police, fire, medical and utilities) to perform their services, not just to the tourists but also to the local residents. This is in agreement with studies by Pizam (1978) and Milman \& Pizam (1988) where it was also found that tourism had increased the performance of the local services. In addition, tourism development on the island also led to more business opportunities especially in running restaurants, and this fortunately, increased the income of the residents. The increase in the amount of investment spending would not just benefit orga- nizations and firms involved in the tourism and hospitality sector, but would also increase job opportunities for the residents. The findings are similar to several studies of positive impacts of tourism (Johnson et al., 1994; McCool \& Martin, 1994; Akis et al., 1996).

The positive impacts consequently lead to a better standard of living for the local residents and this is in agreement with the studies concerning the positive economic impacts of tourism (King et al., 1993; Akis et al., 1996; Haralambopoulos \& Pizam, 1996). Moreover, residents probably would like to see their historical structures being restored and protected not just as attractions to the tourists but also as historical aspects that can be appreciated by future generations. Residents tend to perceive the decrease impacts due to tourism as negative impacts of tourism. Such impacts include, the wildlife (plants, birds and animals), the amount of local taxes collected and the noise level in the area. The fact that tourism development in Langkawi destroys the 'green' environment in the area would probably be the reason for the residents to perceive the wildlife aspect as a negative impact of tourism. The finding is similar to a study by Akis et al. (1996) where they also found that tourism destroyed the natural environment and wildlife.

In addition, the local taxes aspect is perceived as a negative impact probably due to the fact that most of the residents did not benefit from the local taxes collected. However, if most of the respondents in the study consist of government organizations, the aspect would probably be perceived as a positive impact of tourism. As for the aspect of the noise level in the area, residents are probably used to a quiet and peaceful surrounding before the development of tourism on the island. Thus, tourism probably has caused noise pollution from construction of hotels and new roads. The findings are found to be very similar to several studies of perceived tourism impacts (Canaday \& Zeiger, 1991; Kavallinis \& Pizam, 1994; Wang \& Miko, 1997). The findings also reveal that the community spirit among the residents and the pride of local residents are two aspects that did not impact the residents either positively or negatively. This is probably because these two aspects are part of the residents' values and 
beliefs. Even though the residents consist of different racial groups, each group perceives the aspects similarly because they probably share the same values toward the impacts.

In another aspect, the findings also indicate that a model such as Doxey's Irredex Model that describes the changes in community's perceptions and attitudes toward tourism, from positive to negative, as tourism become more apparent to residents, cannot be applied in the case of tourism in Langkawi. It can be seen that residents tend to perceive the impacts of tourism in the area, either positively or negatively depending on how much they would affect their personal lives. In fact, the more dependent the residents are on the positive impacts, the more supportive they are toward tourism development. Thus, it is recommended that policy makers and tourism planners conduct more campaigns and workshops, particularly for the local residents, in order for them to participate in the tourism development of the island. Their participation is important to achieve sustainable tourism development in the area. Campaigns that can be conducted are 'Residents Awareness of Tourism', 'Opportunities in Tourism Industry', 'Government Incentives for Tourism Operators in Langkawi' and others.

As for those who do not support tourism, several actions need to be taken especially by the government so that they would perceive the negative impacts as opportunities that can lead to a better life and moreover, appreciate the positive impacts that benefit them. The government can reduce the negative impacts of tourism in Langkawi by controlling the number of tourists arrivals on the island. A policy stating the code of conduct and code of ethics should also be given to the tourists and the hosts so that they can reduce the negative impacts of tourism development. However, a further study still needs to be undertaken in order to investigate why residents of Langkawi act the way they do toward impacts of tourism in the area. It has been noted in other studies that several factors could also influence residents' perceptions and attitudes toward tourism (Brougham \& Butler, 1981; Liu \& Var, 1986; Milman \& Pizam, 1988). Thus, this would determine a better ground to understand residents' attitudes.

\section{REFERENCES}

Akis, S., Peristianis, N. \& Warner, J. (1988). The impact of tourism development on resident's perception of community life. Journal of Travel Research, 27 (1), 16-21.

Allen, L. R., Hafer, H. R., Long, P. T. \& Perdue, R. R. (1993). Rural residents' attitudes toward recreation and tourism development. Journal of Travel Research, 31 (4), 27-37.

Andereck, K. L. \& Vogt, C. A. (2000). The Relationship between residents' attitudes toward tourism and tourism development options. Journal of Travel Research, 39, 27-36.

Brougham, J. \& Butler, R. (1981). A Segmentation analysis of resident attitudes to social impacts of tourism. Annals of Tourism Research, 7 (4), 569-590.

Butler, R. W. (1975) The Social Implications of Tourist Development. Annals of Tourism Research, (2),100-111.

Caneday, L. \& Zeiger, J. (1991). The social, economic and environmental costs of tourism to a growing community. Journal of Travel Research, 30 (Fall), 45-48.

Churchill, G. A. (1979). A paradigm for developing better measures of marketing constructs. Journal of Marketing Research, 26 (2), 64-73.

DeVillis, R. F. (1991). Scale development: Theory and application applied Social Research methods series, (26), Newbury Park, CA: Sage.

Din, K. H. (1993). Normative and positive aspects of Muslims travel behaviour, In Development and the Muslims (eds.), Din, K.H., Bangi: Universiti Kebangsaan Malaysia, 209-26.

Doxey, G. (1975). A Causation Theory of visitor - Resident irritants: Methodology and research inferences. Proceeding of the Travel Research Association, $6^{\text {th }}$ Annual Conference, San Diego, California. 
Fishbein, M. (1963). An investigation of the relationships between beliefs about an object and attitude toward that Object. Human Relations, 16, 233-240.

Haralambopoulos, N. \& Pizam, A. (1996) Perceived impacts of tourism: The case of Samos. Annals of Tourism Research, 23 (3), 503-523.

Hernandez, S. A., Cohen, J. \& Garcia, H. L. (1996). Residents' attitudes toward an instant resort enclave. Annals of Tourism Research, 23 (4), 755-779.

Jafari, J. (1977). Editor's Page. Annals of Tourism Research, 5, 6-11.

Johnson, J. D., Snepenger, D. J. \& Akis, S. (1994). Residents' perceptions of tourism development. Annals of Tourism Research 21, 629642.

Kavallinis, I. \& Pizam, A. (1994). The environmental impacts of tourism - Whose responsibility is it anyway? The case study of Mykonos. Journal of Travel Research, 33 (2), 26-32.

Kayat, K. \& Propst, D. (2001). Exchanges between residents and tourism development. Malaysian Management Journal, 5 (1\&2), 1-15.

King, B., Pizam, A. \& Milman, A. (1993). Social impact of tourism: Host perceptions. Annals of Tourism Research, 650-65.

Langkawi Development Authority (LADA) (1999). Langkawi Residential/Socioeconomic Study.

Langkawi Residential/Socioeconomic Study (1999) Langkawi Development Authority.

Lankford, S. V. (1994). Attitudes and perceptions toward tourism and rural regional development. Journal of Travel Research, (Winter), 35-48.
Lindberg, K. \& Johnson, R. L. (1997). Modeling resident attitudes toward tourism. Annals of Tourism Research, 24 (2), 402-424.

Liu, J. \& Var, T. (1986). Resident attitudes toward tourism impacts in Hawaii. Annals of Tourism Research, 13 (2), 193-214.

McCool, S. F. \& Martin, S. R. (1994). Community attachment and attitudes toward tourism development. Journal of Travel Research, 33 (3), 29-34.

Milman, A. \& Pizam, A. (1988). Social impacts of tourism on Central Florida. Annals of Tourism Research, 15 (2), 191-204.

Mohammad Shariff, N., Hashim, F. \& Abdul Rahman, N. (2000). Sikap penduduk tempatan terhadap pembangunan pelancongan di Negeri Kedah. Utara Management Review, 1 (2), 39-56.

North Review, (1995). Langkawi soars to greater heights, Published Brochure, Alor Star, Kedah: The State Government of Kedah Darul Aman.

Pizam, A. (1978). Tourism impacts: The social costs to the destination community as perceived by its Residents. Journal of Travel Research, 16 (Spring), 8-12.

Ryan, C., Scotland, A. \& Montgomery, D. (1998). Resident attitudes to tourism development - A comparative study between the Rangitikei, New Zealand and Bakewell, United Kingdom. Progress in Tourism and Hospitality Research, 4, 115-130.

Snaith, T. \& Haley, A. (1999). Residents' opinion of tourism development in the historic city of York, England. Tourism Management, 20, 595-603.

Tinsley, H. O. \& Tinsley, D. (1987). Uses of Factor Analysis in Counseling Psychology research. Journal of Counseling Psychology, 34, 414-424. 
Wang, Chih-Yung \& Miko, P. S. (1997). Environmental impacts of tourism on U.S. National Parks. Journal of Travel Research, 35 (4), 31-36.
Zaichowsky, J. (1985). Measuring the involvement construct. Journal of Consumer Behaviour, 12, 341-52. 